\title{
Prospective scenarios analysis: Impact on demand for oil and its derivatives after the COVID-19 pandemic
}

\author{
Marcus Vinícius Gonçalves Rodrigues ${ }^{1}$ (D), Thamires Eis Duarte ${ }^{1}$, Marcos dos Santos $^{2}$ (D), \\ Carlos Francisco Simões Gomes ${ }^{1}$ (D) \\ ${ }^{1}$ Federal Fluminense University - UFF, Industrial Engineering Department, Niterói, RJ, Brazil. \\ ${ }^{2}$ Military Engineering Institute - IME, Rio de Janeiro, RJ, Brazil.
}

How to cite: Rodrigues, M.V.G., Duarte, T.E., Santos, M. et al. (2021), “Prospective scenarios analysis: Impact on demand for oil and its derivatives after the COVID-19 pandemic", Brazilian Journal of Operations \& Production Management, Vol. 18, No. 2, e20211215. https://doi.org/10.14488/BJOPM.2021.039

\section{ABSTRACT}

Goal: This paper aims to illustrate one of the strategies found in the literature to deal with uncertainties: prospecting scenarios in the demand for oil derivatives after the COVID-19 pandemic (identifying the desirable scenario, the undesirable and the trend, at a national level in the Brazilian market) and proposing a corresponding strategy plan for each prospection in order to minimize the resumption impacts.

Design / Methodology / Approach: This study was carried out with relevant indicators of the oil and gas industry (downstream). Commercialization data (from 2017 to 2020) were compared in order to verify the pandemic impacts. After collecting the data, we used the Momentum approach to prospect the scenarios, suggesting a strategic action plan for each prospection.

Results: The results reveal that, regardless the post-pandemic scenario that we will encounter, the industries belonging to the oil and gas sector will have to define strategies and implement solid action plans to remain competitive in the market. It was also possible to note that the action plan for the desirable and trend scenario has synergy.

Limitations of the investigation: The results obtained in this research refer only to the Brazilian scenario, more specifically to the downstream sector of the oil and gas industry and may differ from other sectors or regions.

Practical implications: This research provides ways for oil and gas companies to be prepared for the post-pandemic future, thus remaining competitive in the market. In addition, as a result of applying the Momentum method, it is possible to see how the sector's indicators relate to each other through the cross-impact matrix.

Originality / Value: This is an unprecedented study that allows the downstream oil and gas companies to be better prepared to the post-COVID-19 scenario. It adds value not only to the oil and gas industry but also to other industries, since it is possible to replicate the method presented here in other contexts with different databases.

Keywords: Oil and Gas Industry; Prospective Scenario; Economic Recession; COVID-19; Operational Research.

\section{INTRODUCTION}

Oil and gas companies play an important role in the global economy, as they are responsible for providing much of the energy needed by the world. According to Ahmad and Zhang (2020), the energy industry has received attention over the last few decades mainly for

Financial support: None.

Conflict of interest: The authors have no conflict of interest to declare.

Corresponding author: cfsg1@bol.com.br

Received: 12 April 2021.

Approved: 1 June 2021.

Editor: Syed Abdul Rehman Khan. 
use in the transportation sector. Political and economic factors, such as restrictions imposed by the governments, demand from the consumer market and the quantity offered, have a significant impact on the prices charged by the oil industry.

According to Branski (2015), the supply chain of the oil and gas industry can be divided into at least two segments: upstream and downstream. The first includes exploration, drilling, completion and production activities - characterized by high costs and qualified labor (it is worth mentioning that, depending on the price of oil sales, companies cannot always achieve the expected economic return), in addition to high investments in structures and technology for the operation of the platforms. Downstream activities include transportation, refining and distribution - a complex transportation network, often linked through gas and oil pipelines and investment in refining technologies and high inventory costs.

The Oil and Gas sector is important and significant for the Brazilians in terms of political, economic and social factors. Silva et al. (2018) showed that this sector represented four per cent of the national gross domestic product (PIB, in the Portuguese acronym) from 2000 to 2015 and Azevedo Filho et al. (2019) gave an emphasis highlighting the creation of jobs and income for the state.

Distribution efficiency is closely linked to the quality of the infrastructure of the country's logistics modes. In Brazil, the main logistical modal used is the road, even though it has less load capacity and, in general, the higher cost per cubic meter transported. Unlike the upstream, the downstream has a very large interface with the end consumer. As a result, the social isolation directly impacted the demand for fuels and, consequently, the supply chain of this segment.

The pandemic caused by COVID-19 started in December 2019 in China, spreading to several countries worldwide in 2020. Trying to contain the advances of the pandemic, these countries, in general, took several actions to contain the spread of the virus, such as restricting trade and services, sanitaries barriers and social isolation. As a result, the energy sector was one of the most affected.

This research is focused on the downstream segment, specifically on analyzing (and comparing) the demand for fuels such as ethanol, gasoline, diesel, fuel oil, liquefied petroleum gas (LPG, in the English acronym and GLP, in the Portuguese acronym) and aviation gasoline/kerosene in the Brazilian market. This segment has a considerable plurality in the chain, with players of different sizes and different areas of activity.

This paper aimed to prospect scenarios, using the Momentum method, for the Brazilian oil derivatives demand after the COVID-19 pandemic. We identified the desirable, undesirable and trend scenario, proposing a corresponding strategy plan for each prospection in order to minimize the resumption impacts.

\section{LITERATURE REVIEW}

\subsection{The COVID-19 impacts in the Oil and Gas Industry}

According to the Global Energy Review 2020 from IEA (International Energy Agency, 2020), the demand for oil and its derivatives in 2020 was expected to be nine million and three hundred thousand barrels per day less than the same period in 2019. This drop is likely to be caused by measures of restriction in one hundred and eighty-seven countries that interrupted the mobility of its inhabitants, which culminated in a nine percent decrease in the global oil demand.

Indupurnahayu et al. (2021) analyzed the changes in the demand for crude oil in Indonesia during the COVID-19 pandemic, emphasizing its effects on the local natural gas market. As a conclusion, they found that COVID-19 caused the demand for oil and its derivatives to fall sharply. However, the same did not happen in the natural gas demand. According to the authors, the use of natural gas in Indonesia is mostly residential (for cooking and heating) and, as people are spending more time at home due to social isolation, residential gas consumption increased. 
Meher et al. (2020) studied the impact of the pandemic in the Indian market by analyzing the volatility of crude oil and natural gas prices. Their conclusion indicates a presence of asymmetric volatility in crude oil prices due to the spread of COVID-19. It is possible to notice a synergy with Indupurnahayu et al. (2021) research, since the volatility in the natural gas price was not verified. Similarly, Qin et al. (2020) said that as a consequence of the low demand, the oil prices dropped dramatically. How prices will return is still unclear to the authors.

The main consequences of the COVID-19 in the oil industry are not restricted to the decrease in production and consumption of crude oil but also involves the potential change in the use of these resources, after the pandemic. Norouzi et al. (2020), developed a study illustrating the economic impacts on the energy market, resulting from the COVID-19. Although the epidemic is not over, the authors also highlighted potential post-pandemic effects on the energy sector. Jiang et al. (2021) analyzed the challenges, lessons and opportunities in the energy sector after the COVID-19 impact on energy demand, focusing on the good aspects of the pandemic.

\subsection{Prospecting Scenarios}

Due to the advent of technology in companies in all sectors, the increase in competitiveness, the level of customer demand and the need to meet sustainable goals, organizations that wish to remain competitive in the market need to plan and create scenarios, trying to be prepared for the future and, as a consequence, trying to be one step ahead of its competitors.

Schwartz (2003) states that for organizations to build the necessary conditions to learn about the future and its various possibilities, it is necessary to choose three to five more representative futures. According to the author, a single scenario leaves the companies vulnerable around a single solution, which makes it difficult to react if any other scenario becomes reality.

Porter (1989) defined a scenario as a consistent view of what the future might become. It is worth noting, however, that this technique does not have the objective of predicting the future, but rather to obtain a direction for the actions of the present. According to Santos et al. (2010), prospective approaches seek to promote transformations, understand the forces that guide the future and negotiate spaces, aiming to anticipate lead changes. In this way, prospective studies want to support decision makers, transforming known information into knowledge.

According to Alves et al. (2020), elaborating scenarios is an endeavor to make admissible descriptions of possible future situations, seeking information about future prospects, analyzing the factors important in decision making. Vieira et al. (2017) noted that can be identified in the literature a series of methodologies that support the construction of scenarios and their integration in the strategic decision making of companies. Oliveira et al. (2018) described ten scenarios methods: Intrerax, IFS or Battelle, TIA, FCM, Momentum, Intuitive Logics, Prospective analysis, Future Mapping, GBN and Morphological analysis.

Parisi et al. (2020), for example, presented a prospective life cycle assessment (LCA) of third-generation photovoltaics under a long-term scenario approach in the European context. Aguilar-Hernandez et al. (2021), performed a meta-analysis to review more than 300 circular economy scenarios in the time frame from 2020 to 2050. Their idea was to model the future of the circular economy analyzing its impacts on gross domestic product, employment, and carbon emissions.

In this paper, we will focus on the Momentum method presented by Gomes et al. (2017). One application of the Momentum method can be found in the research done by Oliveira et al. (2021), where the authors proposed a model to evaluate business projects.

The Momentum method proposed by Gomes et al. $(2017$, p.5) is structured in seven stages and consists in a hybrid approach which integrates the concepts of the main prospective methods that can be found in the literature: 
“A) Understanding or overview of selected system or business, determining its inputs, outputs, mission and future vision, when applicable;

B) Mapping of relevant actors, and their respective influences or areas of influence; Identification of variables, selecting the internal (strengths and weaknesses) and the external variables (threats and opportunities) of the system under study, performing a SWOT analysis;

C) Uncertainties evaluations, and their respective casual factors;

D) Selection of relevant variables;

E) Elaboration of variables retrospective, or historical analysis, in order to define variables settings and to assign their respective probabilities of occurrences;

F) Definition of key indicators and perform of their retrospective analysis;

G) Construction of scenarios, pursuing the most desired --or desirable-- one, and other scenarios which are pertinent".

\section{RESEARCH METHODOLOGY}

This study was done based in the following research stages:

a) Theoretical conceptualization of the COVID-19 impact in the oil and gas industry through the study of academic publications. For this step, we conducted a research in the Scielo, Scopus and Web of Science databases, using the filter: (oil or gas or energy or fuel) and (demand or impact) and (COVID-19). We were able to verify the global impacts of the pandemic in the oil market and we have chosen the works that have synergy with our study;

b) Search for articles in the Scielo, Scopus and Web of Science databases, using the filter: (Prospecting or Prospective or Future) and (Scenario or Scenarios). This step was important for the study of prospecting scenarios methods published in the literature. We decided to use the Momentum method;

c) Definition of the comparative parameters to be used in the research: Oil Derivatives' commercialization in Brazil (hydrated ethanol, gasoline, diesel, LPG, fuel oil, aviation gasoline, aviation kerosene). With these parameters it was possible to analyze how the pandemic has impacted the demand for oil derivatives in the Brazilian market;

d) Collection of data related to the parameters defined in the previous step. We collected the national commercialization data for 2017, 2018, 2019 and 2020 (year of the pandemic) in the databases of the National Agency of Petroleum, Natural Gas and Biofuels (ANP, in the Portuguese acronym);

e) Analysis of the data collected in the previous step to verify whether the pandemic actually impacted the Brazilian oil market (downstream). This step was relevant to see if there was synergy with the global market;

f) Use of Momentum method to prospect three scenarios (the desirable, undesirable and trend scenarios were identified). This step is the most important and longest in our study. We performed the seven stages of the Momentum method in our database;

g) Suggestion of a strategic action plan for each of the scenarios prospected. This consists in an additional step which aims to help the decision maker to deal with the potential future scenarios. 


\section{DATA ANALYSIS AND RESULTS}

\subsection{Oil derivatives commercialized in Brazil from 2017 to 2020}

The oil derivatives commercialization data were collected from various ANP databases, all of them available for public consulting. After that, the numbers trend was analyzed. The results can be found in Table 1 where the data correspond to the period from January to August of the years 2017, 2018, 2019 and 2020.

Table 1: Oil Derivatives' commercialization in Brazil in $\mathrm{m}^{3}$ (From January to August)

\begin{tabular}{ccccc}
\hline Product $/$ Year & $\mathbf{2 0 1 7}$ & $\mathbf{2 0 1 8}$ & $\mathbf{2 0 1 9}$ & $\mathbf{2 0 2 0}$ \\
\hline Hydrated Ethanol & $8,116,976$ & $11,521,898$ & $14,495,314$ & $12,040,092$ \\
\hline Gasoline & $29,819,438$ & $25,935,799$ & $24,970,919$ & $22,371,191$ \\
\hline Diesel & $36,108,020$ & $36,664,628$ & $37,896,174$ & $37,114,696$ \\
\hline LPG & $8,964,445$ & $8,875,164$ & $8,768,439$ & $9,063,219$ \\
\hline Fuel Oil & $2,031,963$ & $1,545,170$ & $1,275,045$ & $1,181,173$ \\
Aviation Gasoline & 34,011 & 33,082 & 29,485 & 24,071 \\
\hline Aviation Kerosene & $4,403,347$ & $4,29,486$ & $4,648,464$ & $2,311,149$ \\
\hline
\end{tabular}

Source: Done by the author with ANP data (Agência Nacional do Petróleo, Gás Natural e Biocombustíveis, 2020)

As can be seen in Table 1, in general, the demand for oil derivatives products decreased significantly in 2020. The demand for hydrated ethanol, for example, which had been growing, decreased seventeen percent in 2020, when compared to the same period in 2019 (from January to August). The only exception was in the LPG sales figures, which can be justified by the increase in domestic consumption resulting from social isolation. All other products had their demand decreasing, some at larger others at lower rates.

\subsection{Prospective Scenarios of Oil Derivatives after COVID-19}

In the following items are some steps of the Momentum method, described in section 2.2 of this work.

\subsubsection{Relevant Actors}

After analyzing the sector, it was possible to identify the main relevant actors involved not only in the production of crude oil, but also the actors involved in the commercialization of refined products (considering the pandemic context). Some of the actors described below were previously mapped in the article presented by Alves et al (2020).

- National Agency of Petroleum, Natural Gas and Biofuels (ANP, in the Portuguese acronym);

- Comptroller General of the Union (CGU, in the Portuguese acronym);

- Ministry of Mines and Energy (MME);

- National Petroleum Industry Organization (ONIP, in the Portuguese acronym);

- Investment Partnership Program (PPI, in the Portuguese acronym);

- Energy research company (EPE, in the Portuguese acronym);

- Pré-sal Petróleo S.A. (PPSA) - responsible for providing technical analysis, aiming to maximize the results from Pre-Salt operations for the Brazilian Federal Government;

- Brazilian Petroleum, Gas and Biofuels Institute (IBP, in the Portuguese acronym);

- Companies qualified to Explore and Produce Crude Oil from the Brazilian fields;

- Companies qualified to refine oil in Brazil;

- Companies qualified to distribute and sell oil products in Brazil;

- Federal, State and Municipal Governments of Brazil; 
- Companies, in general, that operate in Brazil (as we will see later, the demand for oil products will be directly affected by the work regime adopted by such post-pandemic companies (presentially, remote or hybrid);

- Brazilian's Universities and Schools (for the same reason as the previous point).

\subsubsection{SWOT Analysis}

The SWOT analysis represents an important step in the method, since from it are mapped the potential impact factors (internal and external) to the organizations or to the market that are being studied. Table 2 illustrates the history of some variables mentioned below.

Table 2: Oil and Gas figures from 2016 to 2019

\begin{tabular}{|c|c|c|c|c|c|c|}
\hline Year & $\begin{array}{l}\text { Unity of } \\
\text { measure }\end{array}$ & Source & 2016 & 2017 & 2018 & 2019 \\
\hline Oil production & $\begin{array}{c}\text { thousands of } \\
\text { barrels/day }\end{array}$ & $A$ & 2,591 & 2,721 & 2,679 & 2,877 \\
\hline Oil reserves & billions of barrels & $A$ & 12.6 & 12.8 & 13.4 & 12.7 \\
\hline $\begin{array}{l}\text { Natural gas } \\
\text { reserves }\end{array}$ & $\begin{array}{l}\text { trillions of cubic } \\
\text { meters }\end{array}$ & $A$ & 0.39 & 0.38 & 0.38 & 0.38 \\
\hline $\begin{array}{l}\text { Natural gas } \\
\text { production }\end{array}$ & $\begin{array}{c}\text { billions of cubic } \\
\text { meters }\end{array}$ & $A$ & 24.1 & 27.2 & 25.2 & 25.8 \\
\hline $\begin{array}{c}\text { Total effective } \\
\text { refining } \\
\text { capacity }\end{array}$ & $\begin{array}{c}\text { thousands of } \\
\text { barrels/day }\end{array}$ & $A$ & 2,289 & 2,285 & 2,285 & 2,290 \\
\hline $\begin{array}{c}\text { Vehicles' sales } \\
\text { growth }\end{array}$ & $\%$ & B & -20.3 & 1.3 & 13.6 & 10.5 \\
\hline $\begin{array}{c}\text { Remote higher } \\
\text { education }\end{array}$ & $\begin{array}{c}\text { absolute number } \\
\text { of students per } \\
\text { year }\end{array}$ & $\mathrm{C}$ & $1,494,418$ & $1,756,982$ & $2,056,511$ & $2,450,264$ \\
\hline $\begin{array}{c}\text { Hydrated } \\
\text { ethanol sales }\end{array}$ & $\begin{array}{l}\text { thousands of } \\
\text { cubic meters }\end{array}$ & A & $14,585.84$ & $13,641.77$ & $19,384.72$ & $22,544.05$ \\
\hline $\begin{array}{c}\text { Electric vehicle } \\
\text { sales }\end{array}$ & $\begin{array}{c}\text { absolute number } \\
\text { per year }\end{array}$ & $\mathrm{D}$ & 1,091 & 3,296 & 3,970 & 11,858 \\
\hline $\begin{array}{l}\text { Greenhouse } \\
\text { gas emissions }\end{array}$ & $\begin{array}{c}\text { millions of } \mathrm{CO}_{2} \\
\text { tones }\end{array}$ & $E$ & 66 & 67 & 62 & 59 \\
\hline $\begin{array}{c}\text { Proven oil } \\
\text { reserves } \\
\text { worldwide }\end{array}$ & billions of barrels & $A$ & $1,689.8$ & $1,728.3$ & $1,735.9$ & $1,733.9$ \\
\hline
\end{tabular}

Sources: A Adapted from ANP Statistical Yearbook (Agência Nacional do Petróleo, Gás Natural e Biocombustíveis, 2020) B Adapted from FENABRAVE Statistical Yearbook (Federação Nacional da Distribuição de Veículos Automotores, 2019) C Higher Education Census - INEP (Instituto Nacional de Pesquisas Espaciais, 2019) D Adapted from the Brazilian Electric Vehicle Association (Associação Brasileira de Veículo Elétrico, 2020) E Adapted from the Petrobras sustainability report (Petróleo Brasileiro S.A., 2019)

\subsubsection{Opportunities}

a) Oil Production: It refers to the amount of oil produced in Brazil and can be found in Table 2.

b) Oil Reserves: It refers to the proven oil reserves in Brazil and can be found in Table 2.

c) Natural Gas Reserves: It refers to the proven natural gas reserves in Brazil and can be found in Table 2.

d) Natural Gas Production: It refers to the amount of natural gas produced in Brazil and can be found in Table 2 .

e) Reopening of cultural, commercial, business and leisure activities: SEBRAE (Serviço Brasileiro de Apoio às Micro e Pequenas Empresas, 2020), Portuguese acronym for Brazilian Service of Support to Micro and Small Enterprises, makes available on its 
website a panel of all companies in the country. With this database, it is possible to carry out a qualitative analysis of what has already reopened after the period of social isolation. The data in Table 3 show the distribution of companies across the regions of Brazil. As such, the Southeast represents more than half of the companies throughout the national territory. The economic activities with the largest number of companies in these regions are clothing, food, aesthetics, restaurants and transportation. And all these activities are open in the country, with no forecast of closing for lockdown.

Table 3: Quantity of companies in Brazil by region

\begin{tabular}{ccc}
\hline Brazil's regions & Quantity of companies & $\%$ \\
Southeast & $10,087,244$ & $52 \%$ \\
South & $3,444,398$ & $18 \%$ \\
\hline Northeast & $3,223,115$ & $17 \%$ \\
\hline Midwest & $1,575,770$ & $8 \%$ \\
\hline North & 896,898 & $5 \%$ \\
\hline
\end{tabular}

Source: Adapted from SEBRAE (Serviço Brasileiro de Apoio às Micro e Pequenas Empresas, 2020)

f) Total Effective Refining Capacity: It refers to the effective capacity in the Brazilian refineries and can be found in Table 2.

g) Vehicles Acquisition Incentives: The Government extended law No 14,076 in October 2020 to guarantee tax incentives for vehicle manufacturers. The objective of this law is to mitigate the economic impacts of the pandemic and to guarantee the socioeconomic development of the North, Northeast and Midwest regions. With the increase of vehicle manufacturers in the country, the number of vehicles increases, therefore, fuel consumption. The percentage of vehicles sales growth comparing each year with its previous can be found in Table 2 .

\subsubsection{Threats}

h) Adoption of the remote/hybrid journey by companies and schools/universities after the pandemic: According to the study illustrated in the marketing and technology trend report (Institute for Technology, Enterpreneurship and Culture, 2020) done by the institute for technology, entrepreneurship and culture (TEC, in the Portuguese acronym), companies will seek greater incentive to the home office. This adherence can be considered an adaptation to the new economic reality and is aligned with employee productivity and quality of life. Likewise, the remote education has been encouraged in Brazil in the last years (potentiated by the pandemic). The number of enrollments in higher education in the remote mode is illustrated in Table 2.

i) Growth of biofuels: It refers to the growth in the commercialization of biofuels in Brazil. The Hydrated ethanol sales from 2016 to 2019 can be found in Table 2 .

j) Air travel reduction: According to ANAC (Agência Nacional de Aviação Civil, 2020) Portuguese acronym for the national civil aviation agency, the pandemic generated significant impacts on the results of the industry. When comparing data from the domestic market in the second quarter of this year with the same period in 2019, for example, there was a ninety per cent reduction in the demand for air transport, eighty eight per cent in the air transport offer and ninety one per cent in the number of paid passengers carried. The National Bioenergy Union (União Nacional de Bioenergia, 2020) published that aviation gasoline sales in April 2020 fell by approximately forty-four percent and that aviation kerosene sales in April 2020 fell by approximately eighty-five percent when compared to the same period in 2019.

k) Incentive to electric cars in Brazil: It refers to the increase in the sale of electric vehicles in Brazil. The law project $(3,174 / 20)$ establishes a federal policy to encourage the use of 
vehicles powered by electric propulsion and hybrids. According to the Brazilian chamber of deputies (Câmara dos Deputados, 2020), the project is based on tax cuts, creation of priority credit lines for the production of electric vehicles in the country and update of the federal government car fleet. As a result, electric vehicles will have total exemption from the tax on industrialized products (IPI, in the Portuguese acronym) and the hybrids (powered by electric and conventional propulsion) will have a fifty per cent reduction in the tax. The number of electric vehicles sold in Brazil per year can be found in Table 2.

\subsubsection{Weaknesses}

I) High environmental impacts: It refers to the carbon footprint of fossil fuels. According to Almeida et al. (2019), refining is one of the most polluting stages of the process, with the risk of contaminating water, air and soil. Using the data from Alves et al. (2020), the Brazilian company Petrobras makes available through an integrated report its greenhouse gas emissions in millions of $\mathrm{CO} 2$ tones. The greenhouse gas emissions can be found in Table 2.

m) Number of people infected by COVID-19 in Brazil: It refers to the number of people infected by the COVID-19 in Brazil. The pandemic started in Brazil in March 2020, according to data provided by the Ministry of Health of Brazil. In Figure 1 is illustrated the curve of new cases by the notification date in Brazil.

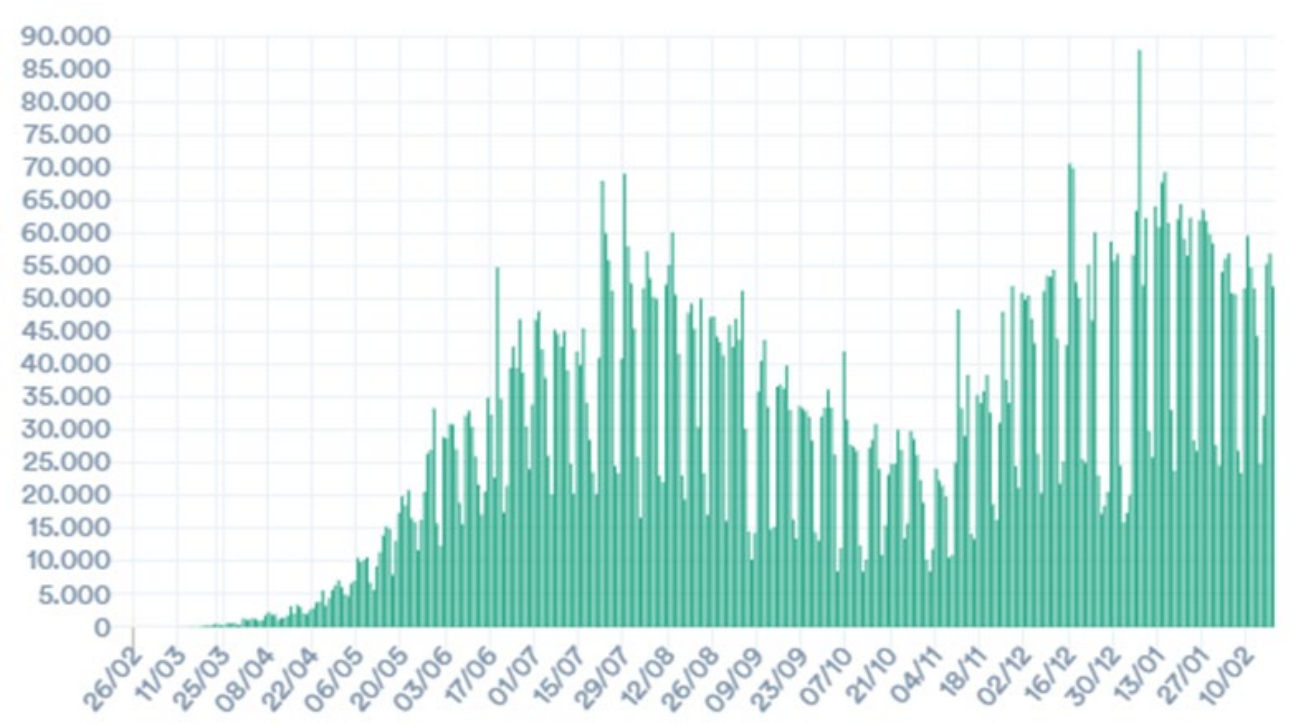

Figure 1: Curve of new cases by notification date in the country

Source: Adapted from COVID-19 Panel - Brazilian Ministry of Health (Brasil, 2021)

n) Limited source of energy (non-renewable): As is known globally, oil is a non-renewable, finite natural resource. This indicator refers to the proven amount of oil reserves in the world and its data can be found in Table 2 .

o) High Operating Costs: The costs involved in upstream and downstream operations exceed the billions of dollars. This indicator illustrates the high cost of producing oil when compared to other energy sources. As an example of the dimensions of such investments, we can mention the bidding rounds for the exploratory blocks in Campos Basin (Brazil): C-M-477 sold for more than two billions of Brazilian reais and C-M-541 sold for more than four billions of Brazilian reais. The values above were obtained from the National Agency of Petroleum, Natural Gas and Biofuels (Agência Nacional do Petróleo, Gás Natural e Biocombustíveis, 2019). 


\subsubsection{Strengths}

p) Storage capacity in refineries: It refers to the refining capacity of oil and its derivatives in Brazil in 2019. According to the National Agency of Petroleum, Natural Gas and Biofuels (Agência Nacional do Petróleo, Gás Natural e Biocombustíveis, 2020), for oil the storage capacity in the Brazilian refineries was $6,657,172 \mathrm{~m}^{3}$ and for oil derivatives and ethanol was $11,184,844 \mathrm{~m}^{3}$.

q) Oil and derivatives sales: It refers to the commercialization of oil products in Brazil and its data can be found in Table 1.

r) Number of gas stations: It refers to the number of gas stations spread throughout the Brazilian territory. According to the National Agency of Petroleum, Natural Gas and Biofuels (Agência Nacional do Petróleo, Gás Natural e Biocombustíveis, 2020), throughout the Brazilian territory we have forty thousand nine hundred and seventy gas stations divided as follows: three thousand two hundred and sixty-one in the north; ten thousand four hundred and ninety-nine in the northeast; three thousand six hundred and seventy-seven in the midwest; fifteen thousand six hundred sixtyone in the southeast and seven thousand eight hundred and seventy-two in the south.

\subsubsection{Uncertainties evaluations, and their respective casual factors}

After analyzing all the indicators, it was possible to see uncertainties in the variables below:

e) Reopening of cultural, commercial, business and leisure activities: As at the time of the study we were still in the middle of the pandemic, the reopening plans took place differently in the cities of the federation, so it was necessary to work with the national average.

h) Adoption of the remote/hybrid journey by companies and schools/universities after the pandemic: As at the time of the study we were still in the middle of the pandemic, we still did not have the data of the companies that decided to adhere to the remote / hybrid work model after the period of social isolation.

o) High Operating Costs: Considered as confidential information, which often measures the operational efficiency of companies, it was not possible to work with the exact operating costs. We had to estimate it.

\subsubsection{Selection of relevant variables}

An important step of the Momentum method consists in the elaboration of a cross impact matrix, based on the indicators and their respective historical data, for the selection of the most relevant variables of the study. In the Table 4 we carry out the judgment of our variables (from $A$ to $R$ ). From this table it is possible to define the most impactful and the most dependent variables. The judgments were made on a scale of 0.5 in 0.5 , ranging from -3.0 to +3.0 , where -3.0 represents the greatest negative impact and +3.0 the greatest positive impact.

The SWOT Matrix enabled the execution of the cross-impact matrix, according to Alves et al (2020), with this analysis it is possible to verify how much a given variable impacts on others and also how much it is impacted by others. The word "impact" is determined by the algebraic sum of the line corresponding to the variable in the crossimpact matrix. The word "Dependency" is determined by the algebraic sum of the column corresponding to the variable in that same matrix. The horizontal sum is called Impact and the vertical sum is Dependency. Table 5 shows the impact and dependence values for each variable. 
Table 4: Cross Impact Matrix

\begin{tabular}{ccccccccccccccccccc}
\hline & $\mathbf{A}$ & $\mathbf{B}$ & $\mathbf{C}$ & $\mathbf{D}$ & $\mathbf{E}$ & $\mathbf{F}$ & $\mathbf{G}$ & $\mathbf{H}$ & $\mathbf{I}$ & $\mathbf{J}$ & $\mathbf{K}$ & $\mathbf{L}$ & $\mathbf{M}$ & $\mathbf{N}$ & $\mathbf{O}$ & $\mathbf{P}$ & $\mathbf{Q}$ & $\mathbf{R}$ \\
\hline $\mathbf{A}$ & - & 0.0 & 1.0 & 2.0 & 0.5 & 1.0 & 2.5 & 0.0 & -2.0 & 0.5 & -1.5 & 3.0 & 0.0 & 3.0 & 2.0 & 1.0 & 3.0 & 2.0 \\
\hline $\mathbf{B}$ & 3.0 & - & 0.5 & 1.0 & 0.5 & 0.5 & 0.0 & 0.0 & -2.0 & 0.0 & -2.0 & 2.0 & 0.0 & 3.0 & 0.5 & 0.5 & 1.0 & 1.0 \\
\hline $\mathbf{C}$ & 1.0 & -0.5 & - & 3.0 & 0.5 & 0.5 & 0.0 & 0.0 & -1.5 & 0.0 & -1.0 & 1.0 & 0.0 & 3.0 & 0.5 & 0.5 & 1.0 & 1.0 \\
\hline $\mathbf{D}$ & 0.0 & 0.0 & 0.0 & - & 0.5 & 0.5 & 0.0 & 0.0 & -1.5 & 0.0 & -1.0 & 1.5 & 0.0 & 3.0 & 1.0 & 1.0 & 1.5 & 2.0 \\
\hline $\mathbf{E}$ & 2.0 & 2.0 & 2.0 & 2.0 & - & -0.5 & 0.0 & -3.0 & 0.0 & 3.0 & 0.0 & 0.0 & 3.0 & 0.0 & 0.0 & 1.0 & 3.0 & 1.5 \\
\hline $\mathbf{F}$ & 1.5 & -0.5 & -0.5 & -0.5 & 0.0 & - & 0.5 & 0.0 & 0.5 & 0.0 & -1.0 & 0.5 & 1.0 & 0.0 & 1.5 & 3.0 & 2.0 & 2.5 \\
\hline $\mathbf{G}$ & 0.5 & -1.5 & -0.5 & -0.5 & 0.0 & -0.5 & - & 0.0 & 1.0 & 0.0 & 0.5 & 1.5 & 0.0 & 0.0 & 0.0 & -1.5 & 2.0 & 3.0 \\
\hline $\mathbf{H}$ & 2.5 & -1.0 & 1.5 & 2.5 & 0.0 & 0.5 & 1.0 & - & 0.0 & 3.0 & 0.5 & 0.5 & 2.0 & 0.0 & 0.0 & 0.0 & 2.5 & 1.5 \\
\hline $\mathbf{I}$ & 1.0 & 1.0 & 1.0 & -0.5 & 0.0 & -0.5 & 0.5 & 0.0 & - & 0.0 & 1.0 & 1.5 & 0.0 & 0.0 & 0.0 & -1.5 & -0.5 & 1.5 \\
\hline $\mathbf{J}$ & 1.0 & 1.0 & 0.0 & 0.0 & 0.0 & 1.0 & 0.0 & 0.0 & 0.0 & - & 0.0 & 1.0 & 1.5 & 0.0 & 1.0 & 1.5 & 2.5 & 0.0 \\
\hline $\mathbf{K}$ & -1.5 & 2.0 & 1.0 & -1.0 & 0.0 & -1.5 & 0.5 & 0.0 & 1.0 & 0.0 & - & -1.0 & 0.0 & -0.5 & -1.0 & 0.5 & -1.5 & -0.5 \\
\hline $\mathbf{L}$ & -1.0 & 0.0 & 0.0 & -0.5 & 0.0 & 0.0 & -0.5 & 0.5 & 1.5 & 0.0 & 2.0 & - & 0.0 & 1.0 & 1.0 & 0.5 & 1.5 & 1.0 \\
\hline $\mathbf{M}$ & 0.5 & 1.0 & 1.0 & 0.5 & 3.0 & 1.0 & 1.5 & 3.0 & 0.0 & -1.5 & 0.0 & 0.0 & - & 0.0 & 0.0 & 0.0 & -3.0 & 0.5 \\
\hline $\mathbf{N}$ & 0.0 & 0.0 & 0.0 & 0.0 & 0.0 & 0.0 & 0.0 & 0.0 & 3.0 & 0.0 & 1.0 & 0.0 & 0.0 & - & 2.0 & 0.0 & 0.5 & 0.5 \\
\hline $\mathbf{O}$ & -0.5 & 0.0 & 0.0 & -0.5 & 0.0 & 0.5 & -1.0 & 0.0 & 1.5 & 0.0 & 1.0 & 0.0 & 0.0 & 1.0 & - & 0.5 & -1.0 & 1.5 \\
\hline $\mathbf{P}$ & 1.0 & 1.5 & 1.5 & 1.0 & 0.0 & 3.0 & 0.0 & 0.0 & 1.0 & 0.0 & 0.5 & 2.0 & 0.0 & 0.0 & 1.0 & - & 2.5 & 2.0 \\
\hline $\mathbf{Q}$ & 3.0 & 3.0 & 2.0 & 2.0 & 0.0 & 3.0 & 0.5 & 0.0 & 1.5 & -1.5 & -1.5 & -1.5 & 0.0 & 0.0 & 0.0 & 2.0 & - & 3.0 \\
\hline $\mathbf{R}$ & 1.0 & -1.0 & -1.0 & 1.0 & 0.5 & 2.0 & 1.0 & 0.0 & 1.0 & 0.0 & 0.0 & 1.0 & 0.0 & 0.0 & 0.5 & 1.5 & 3.0 & - \\
\hline
\end{tabular}

Source: Authors (2020)

Table 5: Impact and dependency values

\begin{tabular}{cccccc}
\hline Variables & Impacts & Dependency & Variables & Impacts & Dependency \\
\hline A & 18.0 & 6.0 & J & -4.5 & -2.5 \\
\hline B & 9.5 & 7.0 & $\mathrm{~K}$ & -5.5 & -3.5 \\
\hline C & 9.0 & 9.5 & $\mathrm{~L}$ & 7.0 & 8.0 \\
\hline D & 8.5 & 11.5 & $\mathrm{M}$ & 7.5 & -5.5 \\
\hline E & 4.0 & 5.5 & $\mathrm{~N}$ & 7.0 & 13.5 \\
\hline F & 10.5 & 10.5 & $\mathrm{O}$ & 3.0 & 10.0 \\
\hline G & 4.0 & 6.5 & $\mathrm{P}$ & 17.0 & 7.5 \\
\hline H & 0.0 & 0.5 & $\mathrm{Q}$ & 12.5 & 10.0 \\
\hline I & -2.5 & 0.0 & $\mathrm{R}$ & 10.5 & 21.0 \\
\hline
\end{tabular}

Source: Authors (2020)

To illustrate the numerical analysis and understand better the relationship between the impact and the dependency of the variables, a graph was plotted. It can be found in Figure 2 .

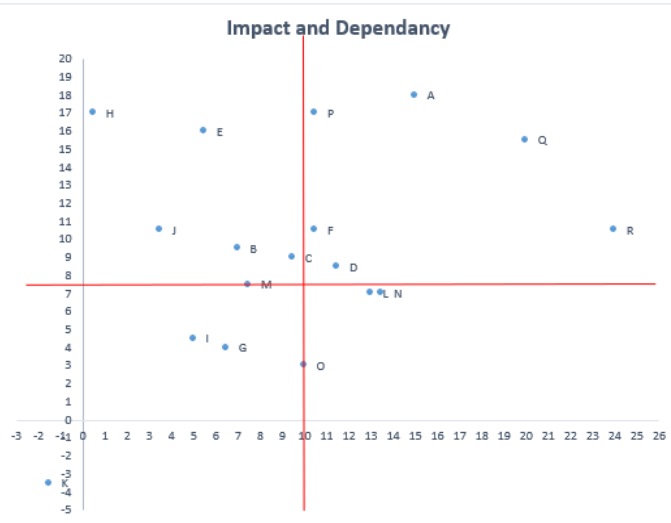

Figure 2: Impact versus Dependency graph

Source: Authors (2020) 
After the analysis of Figure 2, it is possible to admit: that the variables $A, P, Q, R, F$, and D have high impact and dependency, they are more relevant; the variables $H, E, J, B, M$, and $C$ have high impact and low dependency, they have medium relevance; the variables $L, N$ have low impact and high dependency, they have medium relevance; the variables G, I, O and $\mathrm{K}$ have low impact and low dependency, so they have low relevance. The variable $\mathrm{K}$ will not be considered in this research, the reason of that is the very low relevance to the problem.

\subsubsection{Scenario characterization}

From the historical description of each selected variable (from the impact versus dependency analysis), the maximum, minimum and average values were calculated to then stratify the intervals. The results can be found in Table 6 .

Table 6: Variables Configuration

\begin{tabular}{|c|c|c|c|c|c|}
\hline \multirow{2}{*}{ Variable } & \multirow{2}{*}{ Indicator } & \multicolumn{4}{|c|}{ Variables Configuration } \\
\hline & & Very low & Low & Moderate & High \\
\hline A & $\begin{array}{l}\text { Quantity of oil production } \\
\text { (thousands of barrels } \\
\text { per day) }\end{array}$ & $x<1,000$ & $1,000<x<2,000$ & $2,000<x<3,000$ & $x>3,000$ \\
\hline B & $\begin{array}{l}\text { Volume of oil reserves } \\
\text { (billions of barrels) }\end{array}$ & $x<3$ & $3<x<8$ & $8<x<13$ & $x>13$ \\
\hline C & $\begin{array}{l}\text { Volume of natural gas } \\
\text { reserves (in trillions of } \\
\text { cubic meters) }\end{array}$ & $x<0.20$ & $0.20<x<0.30$ & $0.30<x<0.40$ & $x>0.40$ \\
\hline D & $\begin{array}{l}\text { Quantity of natural gas } \\
\text { production (billions of } \\
\text { cubic meters) }\end{array}$ & $x<10$ & $10<x<20$ & $20<x<30$ & $x>30$ \\
\hline $\mathrm{E}$ & $\begin{array}{c}\text { Number of companies in } \\
\text { operation (\%) }\end{array}$ & $x<20$ & $20<x<50$ & $50<x<80$ & $x>80$ \\
\hline $\mathrm{F}$ & $\begin{array}{l}\text { Refining capacity (thousands } \\
\text { of barrels per day) }\end{array}$ & $x<1,500$ & $1,500<x<2,000$ & $2,000<x<2,500$ & $x>2,500$ \\
\hline G & $\begin{array}{l}\text { Sales of cars (\% of growth } \\
\text { comparing with the } \\
\text { previous year) }\end{array}$ & $x<-10$ & $-10<x<10$ & $10<x<20$ & $x>20$ \\
\hline $\mathrm{H}$ & $\begin{array}{l}\text { Remote / hybrid journey } \\
\text { adoption after the } \\
\text { pandemic (\%) }\end{array}$ & $x<20$ & $20<x<50$ & $50<x<80$ & $x>80$ \\
\hline I & $\begin{array}{c}\text { Sales of Biofuels (thousands } \\
\text { of cubic meters) }\end{array}$ & $x<15,000$ & $15,000<x<25,000$ & $25,000<x<35,000$ & $x>35,000$ \\
\hline$J$ & $\begin{array}{l}\text { Sales of aviation fuel } \\
\text { (comparative percentage) }\end{array}$ & $x<-10$ & $-10<x<10$ & $10<x<20$ & $x>20$ \\
\hline L & $\begin{array}{l}\text { Gas emission (millions of } \\
\text { CO2 tones) }\end{array}$ & $x<20$ & $20<x<50$ & $50<x<80$ & $x>80$ \\
\hline M & $\begin{array}{l}\text { New daily cases of people } \\
\text { infected by COVID-19 }\end{array}$ & $x<5$ & $5<x<100$ & $100<x<500$ & $x>500$ \\
\hline $\mathrm{N}$ & $\begin{array}{l}\text { Worldwide oil reserves } \\
\text { (billions of barrels) }\end{array}$ & $x<500$ & $500<x<1,000$ & $1,000<x<2,000$ & $x>2,000$ \\
\hline $\mathrm{P}$ & $\begin{array}{l}\text { Oil storage capacity in } \\
\text { refineries (thousands of } \\
\text { cubic meters) }\end{array}$ & $x<1,000$ & $1,000<x<4,000$ & $4,000<x<8,000$ & $x>8,000$ \\
\hline $\mathrm{Q}$ & $\begin{array}{l}\text { Commercialization of } \\
\text { gasoline (thousands of } \\
\text { cubic meters) }\end{array}$ & $x<10,000$ & $10,000<x<20,000$ & $20,000<x<30,000$ & $x>30,000$ \\
\hline $\mathrm{R}$ & Quantity of gas station & $x<20,000$ & $20,000<x<40,000$ & $40,000<x<60,000$ & $x>60,000$ \\
\hline
\end{tabular}

Source: Authors (2020) 
After the analysis of Table 6 it is possible to define the strategic actions to place the oil and gas industry in a competitive position in the market. Table 7 illustrates the three scenarios: desired (blue), undesired (red) and the trend (green).

Table 7: Desired, undesired and trend scenarios

\begin{tabular}{|c|c|c|c|c|c|}
\hline \multirow{2}{*}{ Variable } & \multirow{2}{*}{ Indicator } & \multicolumn{4}{|c|}{ Variables Configuration } \\
\hline & & Very low & Low & Moderate & High \\
\hline$A$ & $\begin{array}{l}\text { Quantity of oil production } \\
\text { (thousands of barrels } \\
\text { per day) }\end{array}$ & $x<1,000$ & $1,000<x<2,000$ & $2,000<x<3,000$ & $x>3,000$ \\
\hline B & $\begin{array}{l}\text { Volume of oil reserves } \\
\text { (billions of barrels) }\end{array}$ & $x<3$ & $3<x<8$ & $8<x<13$ & $x>13$ \\
\hline C & $\begin{array}{l}\text { Volume of natural gas } \\
\text { reserves (in trillions of } \\
\text { cubic meters) }\end{array}$ & $x<0.20$ & $0.20<x<0.30$ & $0.30<x<0.40$ & $x>0.40$ \\
\hline $\mathrm{D}$ & $\begin{array}{l}\text { Quantity of natural gas } \\
\text { production (billions of } \\
\text { cubic meters) }\end{array}$ & $x<10$ & $10<x<20$ & $20<x<30$ & $x>30$ \\
\hline$E$ & $\begin{array}{c}\text { Number of companies in } \\
\text { operation (\%) }\end{array}$ & $x<20$ & $20<x<50$ & $50<x<80$ & $x>80$ \\
\hline $\mathrm{F}$ & $\begin{array}{c}\text { Refining capacity } \\
\text { (thousands of barrels } \\
\text { per day) }\end{array}$ & $x<1,500$ & $1,500<x<2,000$ & $2,000<x<2,500$ & $x>2,500$ \\
\hline G & $\begin{array}{l}\text { Sales of cars (\% of growth } \\
\text { comparing with the } \\
\text { previous year) }\end{array}$ & $x<-10$ & $-10<x<10$ & $10<x<20$ & $x>20$ \\
\hline $\mathrm{H}$ & $\begin{array}{l}\text { Remote / hybrid journey } \\
\text { adoption after the } \\
\text { pandemic (\%) }\end{array}$ & $x<20$ & $20<x<50$ & $50<x<80$ & $x>80$ \\
\hline I & $\begin{array}{l}\text { Sales of Biofuels } \\
\text { (thousands of } \\
\text { cubic meters) }\end{array}$ & $x<15,000$ & $15,000<x<25,000$ & $25,000<x<35,000$ & $x>35,000$ \\
\hline J & $\begin{array}{c}\text { Sales of aviation fuel } \\
\text { (comparative percentage) }\end{array}$ & $x<-10$ & $-10<x<10$ & $10<x<20$ & $x>20$ \\
\hline L & $\begin{array}{l}\text { Gas emission (millions of } \\
\text { CO2 tones) }\end{array}$ & $x<20$ & $20<x<50$ & $50<x<80$ & $x>80$ \\
\hline M & $\begin{array}{l}\text { New daily cases of people } \\
\text { infected by COVID-19 }\end{array}$ & $x<5$ & $5<x<100$ & $100<x<500$ & $x>500$ \\
\hline $\mathrm{N}$ & $\begin{array}{l}\text { Worldwide oil reserves } \\
\text { (billions of barrels) }\end{array}$ & $x<500$ & $500<x<1,000$ & $1,000<x<2,000$ & $x>2,000$ \\
\hline$P$ & $\begin{array}{l}\text { Oil storage capacity in } \\
\text { refineries (thousands of } \\
\text { cubic meters) }\end{array}$ & $x<1,000$ & $1,000<x<4,000$ & $4,000<x<8,000$ & $x>8,000$ \\
\hline Q & $\begin{array}{l}\text { Commercialization of } \\
\text { gasoline (thousands of } \\
\text { cubic meters) }\end{array}$ & $x<10,000$ & $10,000<x<20,000$ & $20,000<x<30,000$ & $x>30,000$ \\
\hline $\mathrm{R}$ & Quantity of gas station & $x<20,000$ & $20,000<x<40,000$ & $40,000<x<60,000$ & $x>60,000$ \\
\hline
\end{tabular}

Source: Authors (2020)

\subsubsection{Strategic action plan}

After the data analysis and the scenarios construction, we suggest three strategies, aiming to keep the oil and gas industry competitive, one for each scenario:

a) Undesired scenario: This is the worst scenario, for the downstream perspective, for the oil and gas sector after pandemic. In it, the reduction in demand for fossil fuels 
will be exponentialized with the growth of biofuels, with the reduction in the volume of reserves, with a drop in car sales / demand for flights and with the significant change in the journey (hybrid / remote model) of most companies and schools / universities. In this case, we suggest that companies belonging to this sector invest in partnerships with competitors and with companies from other industries in order to reduce their exposure to risks, increase their capital, reduce possible indebtedness, reduce their operating and administrative costs, invest in innovation.

b) Desired scenario: This is the best scenario, for the downstream perspective, for the oil and gas sector after the pandemic. In it, the demand for fossil fuels is favored by the increase in the volume of reserves, probably driven by new technologies or the discovery of new wells, associated with the almost total return from on-site activities, the stagnation of biofuels and the increase in car sales and demand for flights. For this case, we suggest that companies continue to invest in new technologies and innovation, in order to maximize financial results. Partnerships, as in the previous scenario, can be interesting for risk mitigation. However, as it is a finite resource, we also recommend that companies expand their portfolio to other energy matrixes, in order to perpetuate themselves in the energy market.

c) Trend scenario: This is the most likely scenario, for the downstream perspective, for the oil and gas sector after pandemic. In it, the demand for fossil fuels, after suffering a great drop in the pandemic, will return to normal, with the return of face-to-face journeys by most companies, schools and universities associated with the normalization in the sale of cars and in the sale of airline tickets. For this case, the suggestions are the same mentioned in the desired scenario.

\section{CONCLUSION}

The COVID-19 pandemic and the social isolation resulting from it, motivated the demand for fuels to drop dramatically. Because of this, the known forms of work and the relationship between people had to be adapted to a completely new reality. In this perspective, establishing strategies for the future after the pandemic is necessary to maintain the competitiveness of companies.

In this article, we analyze the variables that most impact the downstream of the oil and gas industry, prospecting three possible scenarios (desired, undesired and the trend), according to the Momentum method, defining strategic plans for each scenario prospected.

This research provides ways for oil and gas companies to be prepared for the postpandemic future, thus remaining competitive in the market. In addition, as a result of applying the Momentum method, it is possible to see how the sector's indicators relate to each other through the cross-impact matrix.

The outcomes reveal that, regardless of the post-pandemic scenario that we will encounter, the industries belonging to the oil and gas sector will have to define strategies and implement solid action plans to remain competitive in the market. It was also possible to note that the action plan for the desirable and trend scenario has synergy.

The results obtained in this research refer only to the Brazilian scenario, more specifically to the downstream sector of the oil and gas industry and may differ from other industries or regions. We suggest adapting this study to other industries, to other regions of the World and, if possible, using other prospecting methodologies.

\section{ACKNOWLEDGMENTS}

We thank the postgraduate program of the Federal Fluminense University and the Federal Government of Brazil for the opportunity to carry out this research. 


\section{REFERENCES}

Agência Nacional de Aviação Civil - ANAC (2020), "Anuário Estatístico 2020 - Dados Abertos", available at: https://www.anac.gov.br/noticias/2020/dados-do-2o-tri-revelam-impacto-de-mais-de-6-bilhoes-nasaereas-brasileiras ( accessed 11 November 2020).

Agência Nacional do Petróleo, Gás Natural e Biocombustíveis - ANP (2019), “Rodadas de licitações de petróleo e gás natural", available at: http://rodadas.anp.gov.br/pt/concessao-de-blocosexploratorios-1/16-rodada-de-licitacao-de-bloco/resultados-r16/campos-r16 $\quad$ (accessed 11 November 2020).

Agência Nacional do Petróleo, Gás Natural e Biocombustíveis - ANP (2020), “Anuário Estatístico 2020 Dados Abertos", available at: http://www.anp.gov.br/conteudo-do-menu-superior/31-dadosabertos/6010-anuario-estatistico-2020-dados-abertos (accessed 11 November 2020).

Aguilar-Hernandez, G.A., Rodrigues, J.F.D. and Tukker, A. (2021), "Macroeconomic, social and environmental impacts of a circular economy up to 2050: a meta-analysis of prospective studies," Journal of Cleaner Production, v. 278, p. 123421. http://dx.doi.org/10.1016/j.jclepro.2020.123421.

Ahmad, T. and Zhang, D. (2020), "A critical review of comparative global historical energy consumption and future demand: the story told so far", Energy Reports, Vol. 6, pp. 1973-91. http://dx.doi.org/10.1016/j.egyr.2020.07.020.

Almeida, M.S., Lima, M.G. and Martins, M.L. (2019), "Impactos ambientais causados pela indústria petrolífera", Revista Dissertar, Vol. 1, No. 33.

Alves, C.G.M. F., Colombo, D., Morlin, P. et al. (2020), “Análise de cenários prospectivos: um estudo do mercado brasileiro de petróleo", XIX Simpósio de Pesquisa Operacional e Logística da Marinha, vol. 3, no. 1. http://dx.doi.org/10.5151/spolm2019-027.

Associação Brasileira de Veículo Elétrico (2020), "Vendas/emplacamentos de veículos elétricos no Brasil”, available at: http://www.abve.org.br/wp-content/uploads/2020/07/Ver-quadro.pdf (accessed 11 November 2020).

Azevedo Filho, E.T., Palma, M.A.M., Perestrelo, M. et al. (2019), "The pre-salt layer and challenges to competitiveness in Brazil: critical reflections on the local content policy in the oil and gas sector", The Extractive Industries and Society, Vol. 6, No. 4, pp. 1168-73. http://dx.doi.org/10.1016/j.exis.2019.09.009.

Branski, R.M. (2015), "Logística na Cadeia de Petróleo: uma revisão sistemática", in $29^{\circ}$ Congresso Nacional de Pesquisa em transporte da ANPET, ANPET, Recife, available at: https://aprender.ead.unb.br/pluginfile.php/409397/mod_resource/content/1/AC610_Log\%C3\%ADst ica\%20na\%20Cadeia\%20do\%20Petr\%C3\%B3leo.pdf (accessed 2 November 2020).

Brasil. Ministério da Saúde (2021), "Painel Coronavírus", Coronavírus Brasil, available at https://covid.saude.gov.br (accessed on 19 February 2021).

Câmara dos Deputados (2020), "Projeto cria política de estímulo à produção de veículos elétricos", available at: https://www.camara.leg.br/noticias/693401-projeto-cria-politica-de-estimulo-aproducao-de-veiculos-

eletricos/\#: :text=O\%20Projeto\%20de\%20Lei\%203174,da\%20frota\%20do\%20governo\%20federal.\& text=Os\%20h\%C3\%ADbridos\%20(com\%20propuls\%C3\%A3o\%20el\%C3\%A9trica,redu\%C3\%A7\%C3\% A3o\%20de\%2050\%25\%20do\%20tributo (accessed 11 November 2020).

Federação Nacional da Distribuição de Veículos Automotores - Fenabrave (2019), "Índices e Números. Anuário 2019", available at: http://www.fenabrave.org.br/Portal/conteudo/conteudo/anuarios (accessed on 11 November 2020).

Gomes, C.F.S., Costa, H.G. and Barros, A.P. (2017), "Sensibility analysis of MCDA using prospective in Brazilian energy sector", Journal of Modelling in Management, Vol. 12, No. 3, p. 475-97. http://dx.doi.org/10.1108/jm2-01-2016-0005.

Indupurnahayu, Setiawan, E.B., Agusinta, L. et al. (2021), "Changes in demand and supply of the crude oil market during the COVID-19 pandemic and its effects on the natural gas market", International Journal Of Energy Economics And Policy, Vol. 11, No. 3, pp. 1-6. http://dx.doi.org/10.32479/ijeep.10671.

Institute for Technology, Enterpreneurship and Culture (2020), 'Tendências de Marketing e Tecnologia 2020', available at: https://www.aberje.com.br/wp-content/uploads/2020/04/COVIDInfobase_trendstecnologia.pdf (accessed 11 November 2020).

Instituto Nacional de Pesquisas Espaciais - INEP (2019), “Censo da Educação Superior 2019”, available at: https://www.gov.br/inep/pt-br/areas-de-atuacao/pesquisas-estatisticas-e-indicadores/censo-da- 
educacao-superior/resultados?_authenticator=73b6b0e03f10cadf5ec8ab8e09e6be4f931e571f (accessed 11 November 2020).

International Energy Agency - IEA (2020), “Global Energy Review 2020: the impacts of the Covid-19 crisis on global energy demand and CO2 emissions", available at: https://www.iea.org/reports/globalenergy-review-2020 (accessed 2 November 2020).

Jiang, P., Van Fan, Y. and Klemeš, J.J. (2021), "Impacts of COVID-19 on energy demand and consumption: Challenges, lessons and emerging opportunities", Applied Energy, Vol. 285, pp. 116441.

Meher, B.K., Hawaldar, I.T., Mohapatra, L. et al. (2020), "The impact of covid-19 on price volatility of crude oil and natural gas listed on multi commodity exchange of India", International Journal of Energy Economics and Policy, Vol. 10, No. 5, pp. 422-31. http://dx.doi.org/10.32479/ijeep.10047.

Norouzi, N., Rubens, G.Z., Choupanpiesheh, S. et al. (2020), "When pandemics impact economies and climate change: exploring the impacts of covid-19 on oil and electricity demand in china", Energy Research \& Social Science, Vol. 68, pp. 101654. http://dx.doi.org/10.1016/j.erss.2020.101654.

Oliveira, A.S., Barros, M.D., Pereira, F.C. et al. (2018), "Prospective scenarios: a literature review on the scopus database", Futures, Vol. 100, pp. 20-33. http://dx.doi.org/10.1016/j.futures.2018.03.005.

Oliveira, A.S., Gomes, C.F.S., Clarkson, C.T. et al. (2021), "Multiple criteria decision making and prospective scenarios model for selection of companies to be incubated", Algorithms, Vol. 14, No. 4, pp. 111. http://dx.doi.org/10.3390/a14040111.

Parisi, M.L., Maranghi, S., Vesce, L. et al. (2020), "Prospective life cycle assessment of third-generation photovoltaics at the pre-industrial scale: a long-term scenario approach", Renewable \& Sustainable Energy Reviews, Vol. 121, pp. 109703. http://dx.doi.org/10.1016/j.rser.2020.109703.

Petróleo Brasileiro S.A.(2019), "Relatório de sustentabilidade 2019", available at: https://api.mziq.com/mzfilemanager/v2/d/25fdf098-34f5-4608-b7fa-17d60b2de47d/d19e707148e3-3313-23ec-87fe7a6efe8f?origin=1 (accessed 11 November 2020).

Porter, M.E. (1989), Vantagem Competitiva: Criando e Sustentando um Desempenho Superior. Brasil: Campus.

Qin, M., Zhang, Y.-C. and Su, C.-W. (2020), "The essential role of pandemics: a fresh insight into the oil market", Energy Research Letters, Vol. 1, No. 1, pp. 1-6. http://dx.doi.org/10.46557/001c.13166.

Santos, M.D.M., Coelho, G.M., Santos, D.M.D. et al. (2010), "Prospecção de tecnologias de futuro: métodos, técnicas e abordagens", Parcerias estratégicas, Vol. 9, No. 19, pp. 189-230.

Schwartz, P. (2003), A Arte da Visão de Longo Prazo. Best Seller, São Paulo.

Serviço Brasileiro de Apoio às Micro e Pequenas Empresas - SEBRAE (2020), "Total de Empresas Brasileiras", available at: https://datasebrae.com.br/totaldeempresas/ (accessed 11 November 2020).

Silva, J.F.F.G., Souto, B.F., Rosseti, E.S. et al. (2018), Métricas Industriais para o Desenvolvimento do Setor de Óleo e Gás no Brazil, FGV Energia, Rio de Janeiro, 138 p. available at: https://bibliotecadigital.fgv.br/dspace/bitstream/handle/10438/22063/BOOK\%20completo\%20\%20Me\%CC\%81 tricas\%20Industriais\%20BAIXA_SITE.pdf?sequence=1\&isAllowed=y $\quad$ (accessed 2 November 2020).

União Nacional de Bioenergia (2020), "A queda brutal na venda de combustível", available at: https://www.udop.com.br/noticia/2020/06/04/a-queda-brutal-na-venda-de-combustivel.html (accessed 11 November 2020.

Vieira, J.A.M., Gomes, C.F.S. and Braga, I.E. (2017), "Development of a scenario prospecting model with the use of multicriteria decision aiding: importance of environmental variables", Brazilian Journal of Operations \& Production Management, Vol. 14, No. 2, pp. 210-7. http://dx.doi.org/10.14488/bjopm.2017.v14.n2.a9.

Author contributions: Marcus Vinicius Gonçalves Rodrigues: Conceptualization, Methodology, Formal analysis, Investigation, Writing - Original Draft. Thamires Eis Duarte: Conceptualization, Methodology, Formal analysis, Investigation, Writing - Original Draft. Marcos dos Santos: Validation, Supervision, Writing - Review \& Editing. Carlos Francisco Simões Gomes: Validation, Supervision, Writing - Review \& Editing. 